\title{
ANTROPOLÓGIAI-RÉGÉSZETI EGYÜTTMÜKÖDÉS A BIOLÓGIAI ANTROPOLÓGIAI MARADVÁNYOK RONCSOLÁSOS MINTAVÉTELÉNEK SZABÁLYOZÁSÁRA
}

Pap Ildikó ${ }^{1}$, Hajdu Tamás ${ }^{2}$, Anders Alexandra ${ }^{3}$, Dani János ${ }^{4}$, Kulcsár Gabriella ${ }^{5}$, Révész. László ${ }^{6}$, Mende Balázs ${ }^{5}$, Molnár Erika és Pálfi György ${ }^{7}$

\author{
${ }^{1}$ Magyar Természettudományi Múzeum, Embertani Tár, Budapest; ${ }^{2}$ Eötvös Loránd \\ Tudományegyetem, Embertani Tanszék, Budapest; ${ }^{3}$ Eötvös Loránd Tudományegyetem, \\ Régészettudományi Intézet, Budapest; ${ }^{4}$ Déri Múzeum, Debrecen; ${ }^{5}$ MTA Bölcsészettudományi \\ Kutatóközpont, Régészeti Intézet, Budapest; ${ }^{6}$ Szegedi Tudományegyetem, BTK, Történeti Intézet, \\ Régészeti Tanszék, Szeged; ${ }^{7}$ Szegedi Tudományegyetem, TTIK, Embertani Tanszék, Szeged
}

Pap I., Hajdu T., Anders A., Dani J., Kulcsár G., Révész L., Mende B., Molnár E., Pálfi Gy.: Anthropological-archaeological cooperation for policy to handle requests for destructive/invasive sampling of biological anthropological remains. With the development of the new investigative techniques based on destructive or invasive sampling in biology and chemistry, a necessity to elaborate a sampling policy has emerged. As it is important to conduct research and at the same time to preserve specimens, our recommendation intends to help in deciding whether or not to grant permission for destructive sampling, bearing in mind the importance of the conservation of archaeological heritage and cultural goods (collectively "the elements of our cultural heritage").

In 2015 the Anthropological Interdisciplinary Scientific Committee (AISC), Section of Biological Sciences, Hungarian Academy of Sciences (SBS, HAS) appointed a working group to give recommendation for a Destructive Sampling Protocol for Biological Anthropological Remains. The Recommendation was drawn up by this working group, named "Committee for Preparation Destructive Sampling Protocol of Biological Anthropological Remains" of the AISC, SBS, HAS, with the contributions of physical anthropologists and archaeologists of several institutes and museums, and the members of the Archaeological Scientific Committee, HAS. The Recommendation was read and approved by the Committee of Anthropology, SBS, HAS and Archaeological Scientific Committee, HAS, in 2017.

Keywords: Destructive sampling policy; Recommendation; Biological anthropological remains.

\section{Bevezetés}

Az MTA Antropológiai Osztályközi Tudományos Bizottság (AOTB) a 2015-ös év folyamán tárgyalt először az interdiszciplináris kutatások alapját biztosító mintavételek egységes protokolljának szükségességéről. A szakmai követelmények összeállítására elindult az együttmüködés a régészeti és biológiai antropológiai területek között. Az AOTB megbízta a Bizottság elnökét, hogy írásban forduljon az MTA Régészeti Tudományos Bizottság elnökéhez, kérve az MTA Régészeti Tudományos Bizottság (RTB) együttmüködését a protokoll kidolgozásában. 2016 első hónapjaiban megalakult a Biológiai Antropológiai Mintavételi Protokoll-Előkészítő Bizottság (BAMPEB), amelynek tagjai a két legnagyobb hazai gyüjteményt is képviselő négy AOTB tag: Molnár Erika, Pap Ildikó, Hajdu Tamás, Pálfi György; az MTA BTK Régészeti Intézet 
képviselője, külső szakértő: Mende Balázs; az MTA RTB képviselői: Anders Alexandra, Dani János, Kulcsár Gabriella és Révész László; a vidéki múzeumok képviselője: Dani János. A bizottság tagjainak munkája és a folyamatos egyeztetés eredményeként állt össze a konszenzuson alapuló javaslat a biológiai antropológiai maradványok roncsolásos mintavételi szabályzatára. ${ }^{1}$

Az alábbiakban mutatjuk be az MTA AOTB és az MTA RTB által 2017-ben elfogadott Protokoll-javaslatot, amely arra szolgál, hogy ezeknek az irányelveknek alapján a gyüjteményeket kezelö intézmények kidolgozhassák saját hivatalos szabályzataikat.

\section{JAVASLAT - BIOLÓGIAI ANTROPOLÓGIAI MARADVÁNYOK RONCSOLÁSOS MINTAVÉTELI SZABÁLYZATA}

\section{Általános elvek}

1) A gyüjteményekben őrzött emberi maradványok kulturális és biológiai örökségünkhöz tartoznak. Megőrzésük fontosságának tudatában, és azt kiemelten szem elött tartva fontos, hogy minél sokrétübb, tudományos és össztársadalmi célú hasznosításuk is megtörténjen.

2) A gyüjteményekben őrzött emberi maradványok vizsgálatánál a tudományos és a muzeológiai/gyüjteményi érdekek együttes teljesülésére kell törekedni.

3) Az embertani leletek túlnyomó többsége régészeti feltárásokon kerül elö, és azok többségét múzeumokban, szakmúzeumokban, illetve szakgyüjteményekben őrzik, kezelik és kutatják, így ezek a maradványok egyidejüleg régészeti leletnek és múzeumi, szakmúzeumi, szakgyüjteményi objektumnak minősülnek.

4) Az új molekuláris biológiai és egyéb műszeres vizsgálati technikák fejlődésével ugrásszerüen nőtt a gyüjteményekben örzött embertani leletekből nyerhető tudományos információk mennyisége és azok jelentősége. Ezzel párhuzamosan az utóbbi években a gyüjteményekbe érkezett hazai és külföldi mintavételi kérések száma is jelentősen megszaporodott.

5) A roncsolásos mintavétellel járó technikák - a nem megfelelő mintavétel vagy nem kellöképpen kidolgozott tudományos háttér esetén - visszafordíthatatlan károkat okozhatnak. Ezért a mintavételt minden esetben elözetes kontrollhoz és különböző szintü engedélyekhez kell kötni.

6) Az embertani leletek megóvása elsődleges szempont, ezért a mintavétel során minden esetben törekedni kell a roncsolás mértékének minimalizálására.

\section{Javasolt eljárás}

\section{I) Engedélyeztetési eljárás/protokoll}

A roncsolásos mintavételekhez előzetes Engedély kérése kötelező. Az egyedi nyilvántartásra kötelezett gyüjtemények esetében az engedély iránti kérelmet (lásd a III.

\footnotetext{
1 Az MTA VIII. Biológiai Tudományok Osztálya Antropológiai Osztályközi Tudományos Bizottságának (AOTB) jelenlegi elnöke Pálfi György (SZTE TTIK Embertani Tanszék), társelnöke Gyenis Gyula (ELTE Embertani Tanszék), titkára Molnár Erika (SZTE TTIK Embertani Tanszék). A MTA BTO AOTB Biológiai Antropológiai Mintavételi Protokoll-Elökészítő Bizottság vezetője Pap Ildikó (MTM Embertani Tár) volt.
} 
sz. pontot) a gyüjteményt kezelő szakember, kurátor véleményezi, és az engedélyezésről az illetékes vezető (föigazgató, igazgató, intézetvezető, tanszékvezető stb.) dönt. Fellebbezni az érintett gyüjtemény föhatóságánál lehet. A régészeti leletként és gyüjteményi objektumként egyaránt értelmezendő embertani maradványokból (lásd Általános elvek 3. pont) történő roncsolásos mintavételek szükségességéröl és annak módjáról a feltárást követő 5 éven belül a gyüjtemény felelőse csak a feltáró és/vagy feldolgozásért felelős régész (Régészeti partner) véleményét figyelembe véve, és a Régészeti partnerrel közösen kialakított és írásban is rögzített konszenzus alapján dönthet. Ilyen jellegü leletek vonatkozásában a gyüjtemény felelőse a feltárást követő öt éven túl is törekszik arra, hogy roncsolásos mintavétel esetén a régészeti partnerrel egyetértésben döntsön a mintavételi kérelemröl. A roncsolásos mintavételt igénylő kutatást kezdeményező és koordináló partner (továbbiakban: Kutató partner) a szóban forgó emberi maradványokat őrző és kezelő intézményhez (továbbiakban: Gyüjteményi partnerhez) írásos mintavételi kérelmet nyújt be, amelyet Gyüjteményi partner a vonatkozó adminisztrációs elöírások szerint archivál.

A kérelem kötelező mellékletét képezi a Munkaterv, amely részletezi a tervezett kutatás céljait, előzményeit, technikai, pénzügyi, humánerőforrás feltételeit, tervezett időrendjét, várható eredményeit, ill. azok közlésének/diffúziójának terveit. Régészeti leletnek minősülő emberi maradvány esetében a feltárást követő 5 éven belül a Kutató partner a Munkatervet a Régészeti partnerrel közösen készíti és azt közös aláírással látja el. 5 évnél régebbi feltárás esetén is célszerü és fontos a Régészeti partnerrel egyeztetett Munkaterv kialakítása. A csatolt régészeti véleményt Gyüjteményi partner ebben az esetben is figyelembe veszi a döntés meghozatalánál. Amennyiben Kutató partner nem rendelkezik a Munkatervben szereplő technikai, pénzügyi, humánerőforrás feltételek valamelyikével és a Munkaterv megvalósításához további külső intézmény(ek), laboratórium(ok) szolgáltatásait tervezi felhasználni, a benyújtott kérelemhez csatolnia kell az érintett külső partnerrel/partnerekkel kötött megállapodás vonatkozó részének másolatát.

Fontos, hogy az illetékes vezető (Gyüjteményi partner) az intézményi szakmai testület javaslatának figyelembe vételével döntsön. Speciális tudást igénylő szakember, illetve vitás esetekben külső szakember is bevonható a testületbe. Az engedélyezési eljárás időtartama általában 30 nap. Kivételes esetben (pl. több külső szakértő bevonásának szükségessége) az eljárási idő meghosszabbítható, amiről a kérelmezőt időben értesíteni kell. Amennyiben a mintát nem az adott intézményben elemzik, szükséges és fontos, hogy az intézmény az engedélyezési eljáráshoz a kutatásért felelős Kutató partnerrel szerződést kössön (lásd a II. pontot). A szerződésben egyebek mellett pontosan rögzítendő a mintavétel módja, a minták kezelése, továbbadása, valamint az eredmények közlésének feltételei és a vizsgálat időbeli korlátai.

\section{II) Szerződéstervezet}

Javasoljuk, hogy a szerződéstervezet az alábbi, egyenrangúan lényeges szempontokat tartalmazza, a Munkatervvel összhangban.

1) Tudományos program rövid összefoglalása.

2) A várható új tudományos eredmények rövid felsorolása (hangsúlyozva azok biológiai és régészeti/történeti jelentőségét).

3) A tervezett mintavétel specifikációja (módszer, minta típusa, mennyisége).

4) A mintavétel tervezett ideje és helye. 
5) A minta elemzésének módja és helyszíne - külső partner-labor esetén annak pontos adatait, felelőseit és a vonatkozó szerződések iktatószámait is feltüntetve.

6) A mintavételre szánt emberi maradványok lehető legpontosabb megnevezése, egyedi nyilvántartású szakanyag esetében a maradvány nyilvántartási száma.

7) A vizsgálat pénzügyi fedezete.

8) A kutatás tervezett befejezésének ideje.

9) Az eredmények közlésének tervezett helye, ideje.

10)Régészeti lelet kategóriába tartozó biológiai antropológiai maradványoknál a régészeti feltárást követő 5 éven belül a Régészeti partner hozzájárulása. A hatályos törvényi elöírásokkal összhangban a régészeti feltárást követő öt éven belül a mintavételhez meg kell kérni a Régészeti partner és az elsődleges vizsgálatokat végző antropológus hozzájárulását. Öket - amennyiben arra lehetőség van - a mintavételről, és az azzal kapcsolatos kutatásról a későbbiek során is tájékoztatni kell. Ha azt a körülmények lehetővé teszik, a hatékonyabb szakmai együttmüködések érdekében javasolható bevonásuk az újabb kutatásokba is.

11)A szerződésben rögzíteni kell a mintavétel során keletkezett termékek (PCR termék, extraktum, maradék csontpor stb.) sorsát. Rögzíteni szükséges továbbá, hogy a maradék minta és bármilyen, az elemzés során keletkezett információ továbbadása más intézmény számára kizárólag a Gyüjteményi partner előzetes írásos hozzájárulása alapján lehetséges. Ugyanez vonatkozik a termékből vagy a fel nem használt mintából további, más jellegü vizsgálat elvégzésére abban az esetben is, ha azt az eredeti szerződés szerinti Kutató partner végzi.

12)A Kutató partner nem zárhatja el Gyüjteményi partner elől a vizsgálatok során keletkező eredményeket, azokról és a publikációs tervekről, valamint a vizsgálatok és a publikációs tevékenységek során felmerült problémákról tájékoztatni köteles. Amennyiben a szerződésben meghatározott idő alatt meghiúsul a mintából kinyert tudományos információ széleskörü elérhetőségének biztosítása (publikálás, nyilvános adatbázisba történő feltöltés), az eredmények sorsáról a Felek együttesen, közös konszenzus mentén döntenek.

13)Amennyiben a szerződésben meghatározott idő alatt a Kutató Partner hibájából nem valósul meg a kivett minta vizsgálata, azt maradéktalanul vissza kell szolgáltatnia a Gyüjteményi partner részére. Fontos, hogy Felek a mintákat szakszerüen kezeljék és tárolják, azok későbbi felhasználhatósága érdekében.

\section{III) Javaslatok a „Kérelem elbírálásának szempontjai”-ra}

A kérelmek elbírálása során a következő szempontokat kell mérlegelni és ellenőrizni.

1) A tervezett kutatás tudományos értéke.

2) Tudományos program kidolgozottsága.

3) A program kivitelezhetősége.

4) Alkalmas-e a módszer a kérdés megválaszolására.

5) Mintavétel szükségessége, módja, kivitelezése.

6) A választott mintavételi eljárás valóban a legkevésbé roncsoló hatású-e.

7) A mintát vevő személy rendelkezik-e a mintavételhez megfelelő tapasztalattal, tudással, ill. eszközzel.

8) Amennyiben releváns, a vizsgálat összhangban van-e a Gyüjteményi partner, ill. a feldolgozásért felelős régész, valamint az elsődleges biológiai vizsgálatokat végző antropológus hosszú távú érdekeivel és kutatási stratégiájával. 
9) Amennyiben releváns és szükséges, rendelkezik-e a mintavétel a megfelelő régészeti támogatással, és az írásban az engedélyező Gyüjteményi partnerhez eljutott-e.

10)Régészeti leletnek minősülő emberi maradványoknál a régészeti feltáráshoz viszonyított 5 éven belül tervezett mintavétel esetében a Kutató partner a csatolt Munkatervet a Régészeti partnerrel közösen készítette-e (amennyiben Kutató partner nem azonos a Régészeti partnerrel).

11)A vizsgálatra tervezett idő racionális-e, és összhangban van-e a szakterület dinamikájával (azaz, hogy a kutatás megvalósulása esetén esély lehet-e az eredmények színvonalas közlésére a kutatásra tervezett idő alatt).

12)A vizsgálat eredményeinek megfelelő szintű közlését a Kutató partner tervezi-e, és ezek a tervek reálisnak, arányosnak tünnek-e a mintavétel anyagához viszonyítva.

13)A tudományos program összeegyeztethető-e már folyamatban levő vizsgálatokkal, nem merül-e fel érdekütközés.

14)Nem merül-e fel a Gyüjteményi partner és a hazai tudományosság érdekeinek sérelme.

15)Biztosított-e a vizsgálat pénzügyi fedezete, pályázatok esetében van-e szándéknyilatkozat?

16) Amennyiben a kérelmező korábban az adott vagy más hazai gyüjteményekből vett mintát, betartotta-e a megállapodást.

17)Megfelelően feltüntette-e Kutató partner a Gyüjteményi partnert, ill. a Régészeti partnert, valamint az elsődleges biológiai vizsgálatokat végző antropológust (és amennyiben ismert, az előbbiekben említett régész és antropológus intézményeit) korábbi, a szóban forgó vizsgálattal kapcsolatos publikációinál? Elönyt jelent, ha a kutatásban (főleg nagy projektek esetében) a Gyüjteményi partner intézménye társintézményként vesz részt.

\section{IV) A mintavétel lebonyolítása}

1) Az engedély megszerzése után a mintavétel ellenőrzése is kötelező. A mintavétel a kérelmezővel kapcsolatot tartó szakalkalmazott jelenlétében és ellenőrzésével kell, hogy megtörténjen.

2) A mintavétel során lényeges, hogy fényképekkel illusztrált dokumentáció készüljön, amely tartalmazza a mintavétel előtti és utáni állapotot, valamint a kivett mintát. A fényképeken szerepelnie kell a nyilvántartási, és sír (objektum/strat.) számnak is.

3) A fényképes dokumentációban szerepeljenek a mintavétellel érintett területen mutatkozó esetleges patológiai elváltozások (pl. fogak állapota stb.).

4) Javasoljuk, hogy a pars petrosa területét érintő, vagy más, nagymértékü roncsolással járó mintavétel esetén a mintavételt megelőzően készüljön az archiválás és rekonstruálás szempontjából releváns technológiájú adatrögzítés. CT-felvétel és más, sugárterheléssel járó adatrögzítés esetén ki kell választani az emberi maradvány endogén DNS-ében legkisebb károsításhoz vezető beállításokat.

5) A dokumentációkat papíralapú és elektronikus formában is el kell készíteni, és a gyüjtemény digitális nyilvántartási rendszereiben kell őrizni.

6) Az engedélyben leírt kérelem tartalma, a projekt programja (beleértve a kivett minták listáját is) az eredmények közlését megelőzően csak a szerződésben részt vevő partnerek hozzájárulásával válhat hozzáférhetővé. 


\section{V) Javaslat az „Eredmények közzétételének feltételei”-re}

1) Az intézményi érdek érvényesülésének egyik megjelenése a mintavételben érintett szakanyag feldolgozásában, a mintavevő kutatási programjában szereplő és/vagy a mintavétel szakmai előkészítésében közremüködő szakalkalmazott(ak) társszerzősége az eredmények közzétételekor a nemzetközi gyakorlat szerint.

2) A publikálást követően a tanulmány(ok) egy-egy példányát el kell juttatni a Gyüjteményi partnernek, a Régészeti partnernek és az elsődleges biológiai vizsgálatokat végzö antropológusnak.

3) Az intézmény, gyüjtemény megnevezése a közleményben kötelezö.

4) Amennyiben az új tudományos eredmény közlésénél a szerző az elsődleges régészeti és/vagy biológiai antropológiai kutatás eredményeit felhasználja, annak hivatkozása a tanulmányban kötelező.

\section{VI) Javaslat a „Szerződés be nem tartása esetén életbe lépő szankciók”-ra}

A javaslat szerint megkötendő szerződésnek tartalmaznia kell, hogy a mintavételezést kérő tudomásul veszi, hogy amennyiben a szerződést megszegi, a későbbi mintavételi lehetőségekből kizárható. Súlyos szerződésszegés esetén a korábban engedélyezett mintavétel során kivett minták tudományos vizsgálatát és az abból nyert tudományos eredmények közlésének jogát az adott intézmény, múzeum, szakgyüjtemény visszavonhatja.

\section{VII) A későbbiekben elkészítendő melléklet}

Engedélykérő lap az egyedi nyilvántartású biológiai antropológiai maradványokból történő roncsolásos mintavétel engedélyezéséhez.

A roncsolásos mintavételek engedélyezési eljárásához kapcsolódó dokumentumok mindegyikét javasoljuk az intézmények honlapján magyar és angol nyelven is közzétenni.

Budapest, 2017. MTA AOTB - MTA RTB

$\begin{array}{ll}\text { Levelezési cím: } & \text { Pap Ildikó } \\ \text { Mailing address: } & \text { Embertani tár } \\ & \text { Magyar Természettudományi Múzeum } \\ & \text { Ludovika tér 2-6. } \\ & \text { H-1082 Budapest } \\ & \text { Hungary } \\ & \text { pap.ildiko@ nhmus.hu } \\ & \\ \text { Levelezési cím: } & \text { Pálfi György } \\ \text { Mailing address: } & \text { Szegedi Tudományegyetem, Természettudományi és Informatikai Kar } \\ & \text { Embertani Tanszék } \\ & \text { Közép fasor 52. } \\ & \text { H-6726 Szeged } \\ & \text { Hungary } \\ & \text { gypalfi@ @otmail.com }\end{array}$

